\title{
An electroplated copper-silver alloy as antibacterial coating on stainless steel
}

\author{
Ciacotich, Nicole; Din, Rameez Ud; Sloth, Jens J.; Møller, Per; Gram, Lone
}

Published in:

Surface and Coatings Technology

Link to article, DOI:

10.1016/j.surfcoat.2018.04.007

Publication date:

2018

Document Version

Peer reviewed version

Link back to DTU Orbit

Citation (APA):

Ciacotich, N., Din, R. U., Sloth, J. J., Møller, P., \& Gram, L. (2018). An electroplated copper-silver alloy as antibacterial coating on stainless steel. Surface and Coatings Technology, 345, 96-104.

https://doi.org/10.1016/i.surfcoat.2018.04.007

\section{General rights}

Copyright and moral rights for the publications made accessible in the public portal are retained by the authors and/or other copyright owners and it is a condition of accessing publications that users recognise and abide by the legal requirements associated with these rights.

- Users may download and print one copy of any publication from the public portal for the purpose of private study or research.

- You may not further distribute the material or use it for any profit-making activity or commercial gain

- You may freely distribute the URL identifying the publication in the public portal

If you believe that this document breaches copyright please contact us providing details, and we will remove access to the work immediately and investigate your claim. 


\section{Accepted Manuscript}

An electroplated copper-silver alloy as antibacterial coating on stainless steel

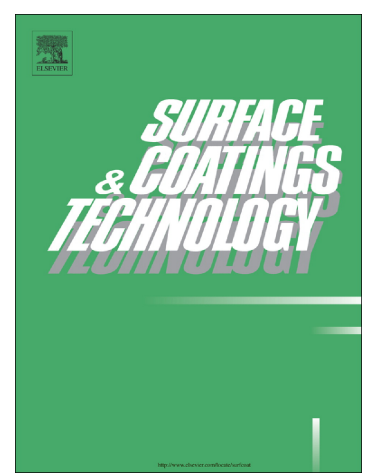

Nicole Ciacotich, Rameez Ud Din, Jens J. Sloth, Per Møller, Lone Gram

PII: S0257-8972(18)30362-1

DOI: doi:10.1016/j.surfcoat.2018.04.007

Reference: SCT 23291

To appear in:

Surface \& Coatings Technology

Received date: 14 September 2017

Revised date: 1 April 2018

Accepted date:

2 April 2018

Please cite this article as: Nicole Ciacotich, Rameez Ud Din, Jens J. Sloth, Per Møller, Lone Gram , An electroplated copper-silver alloy as antibacterial coating on stainless steel. The address for the corresponding author was captured as affiliation for all authors. Please check if appropriate. Sct(2017), doi:10.1016/j.surfcoat.2018.04.007

This is a PDF file of an unedited manuscript that has been accepted for publication. As a service to our customers we are providing this early version of the manuscript. The manuscript will undergo copyediting, typesetting, and review of the resulting proof before it is published in its final form. Please note that during the production process errors may be discovered which could affect the content, and all legal disclaimers that apply to the journal pertain. 


\section{Manuscript cover page}




\section{An electroplated copper-silver alloy as antibacterial coating on stainless steel}

Nicole Ciacotich ${ }^{1,2}$, Rameez Ud Din ${ }^{3}$, Jens J. Sloth ${ }^{4}$, Per Møller $^{3}$ and Lone Gram ${ }^{2 *}$

${ }^{1}$ Elplatek A/S, Bybjergvej 7, DK-3060 Espergærde, Denmark

${ }^{2}$ Department of Biotechnology and Biomedicine, Technical University of Denmark, Matematiktorvet bldg. 301, DK-2800 Kgs Lyngby, Denmark

${ }^{3}$ Department of Mechanical Engineering, Technical University of Denmark, Nils Koppels Alle bldg. 425, DK-2800 Kgs Lyngby, Denmark

${ }^{4}$ National Food Institute, Technical University of Denmark, Kemitorvet bldg. 201, DK-2800 Kgs Lyngby, Denmark

*corresponding author: gram@ bio.dtu.dk 


\begin{abstract}
Transfer and growth of pathogenic microorganisms must be prevented in many areas such as the clinical sector. One element of transfer is the adhesion of pathogens to different surfaces and the purpose of the present study was to develop and investigate the antibacterial efficacy of stainless steel electroplated with a copper-silver alloy with the aim of developing antibacterial surfaces for the medical and health care sector. The microstructural characterization showed a porous microstructure of electroplated copper-silver coating and a homogeneous alloy with presence of interstitial silver. The copper-silver alloy coating showed active corrosion behavior in chloridecontaining environments. ICP-MS measurements revealed a selective and localized dissolution of copper ions in wet conditions due to its galvanic coupling with silver. No live bacteria adhered to the copper-silver surfaces when exposed to suspensions of $S$. aureus and E. coli at a level of $10^{8}$ $\mathrm{CFU} / \mathrm{ml}$ whereas $10^{4} \mathrm{CFU} / \mathrm{cm}^{2}$ adhered after 24 hours on the stainless steel controls. In addition, the $\mathrm{Cu}-\mathrm{Ag}$ alloy caused a significant reduction of bacteria in the suspensions. The coating was superior in its antibacterial activity as compared to pure copper and silver electroplated surfaces. Therefore, the results showed that the electroplated copper-silver coating represents an effective and potentially economically feasible way of limiting surface spreading of pathogens.
\end{abstract}




\section{Introduction}

Healthcare-associated infections (HCAIs) are one of the major causes of patient morbidity during hospitalization [1]. The European Centre for Disease Prevention and Control estimated that, on any given day in 2011-12, 81089 patients were affected by HCAIs in European acute care hospitals, and the total annual number of patients with an HCAI was estimated at 3.2 million [2]. In $2014,8 \%$ of the patients hospitalized for more than two days in an intensive care unit (ICU) in one of the 15 European countries reporting data, had at least one ICU-acquired healthcareassociated infection [3]. In 2015, the percentage of patients affected by ICU-HCAIs increased to $8.3 \%[4]$.

High frequency of HCAIs such as urinary tract infections, pneumonia, post-surgical complications is often associated with the use of invasive devices [1], but also a range of items including hospital furniture (bedrails, frames, door handles) can easily carry pathogenic microorganisms and be a vehicle of proliferation and transmission. Live bacteria adhere easily to different surfaces [5] and this can lead to the formation of structured and specialized bacterial communities (biofilms), which are often less sensitive to antimicrobial agents, such as disinfectants and surfactants. Thus, surfaces that minimize or even prevent bacterial adhesion could be a leading strategy in the control of HCAIs.

Surface treatments with antibacterial activity are receiving increasing attention and scientific interest since this could be a way of limiting transfer of bacteria and other infectious agents. Copper surfaces appear to be one of the best candidates due to their inherent biocidal properties [6], [7], [8], especially in environments where normal sanitization techniques are not sufficient to control the presence (or proliferation) of microorganisms or when the pathogenic agents have developed resistance against the compounds used [7], [9]. When exposed to dry air, copper will 
be oxidized, however, this does not affect its biocidal properties, which makes it suitable for prolonged exposures under those conditions [10].

On the other hand, copper is also a fundamental trace element present in human body and it is necessary in a number of biological processes in most living organisms. More than 30 types of copper-containing proteins have been discovered as far [7].

The biocidal properties of copper are due to combination of several mechanisms that involve the redox couple $\mathrm{Cu}^{+} / \mathrm{Cu}^{2+}[8],[11]$. Copper ions have the ability to cycle between $\mathrm{Cu}^{2+}$ and $\mathrm{Cu}^{+}$at biologically relevant redox-potentials and $\mathrm{Cu}^{+}$is considerably more toxic to bacteria than $\mathrm{Cu}^{2+}$ [6], [12]. $\mathrm{Cu}^{+}$ions are Fenton active, i.e. they can generate highly reactive oxygen species (ROS) when the further oxidization from $\mathrm{Cu}^{+}$to $\mathrm{Cu}^{2+}$ occurs, and ROS can cause peroxidation and oxidation of proteins [13], [14]. Free copper ions in high concentrations can also damage Fe-S clusters in metallo-proteins by occupying the metal site and therefore inactivating the protein [15]. In Escherichia coli, Fe-S clusters are specific target for copper toxicity, however, copper ions decrease oxidative DNA damage when E. coli cells were exposed to hydrogen peroxide [14], [15], [16]. Therefore, this suggests that in vivo copper ion toxicity in bacteria is not mediated by oxidative DNA damage and membrane proteins or membrane lipids are probably the major targets of copper toxicity [14], [16].

Copper and copper alloys like bronze and brass are widely used in applications that foresee skin contact such as jewelry, electronics and hydraulic systems. Furthermore, copper or copper alloys items such as door knobs, bathroom fixtures, tables, armrests, etc., are already available on the market and had recently received more interest [6].

One concern of such surface alloys could be the development of bacterial Cu-resistance and cross-resistance to antibiotics. It had been demonstrated [23] that especially resistant strains, such 
as Gram-positive staphylococci and micrococci, Kocuria palustris, and Brachybacterium conglomeratum can survive on dry copper surfaces for $48 \mathrm{~h}$ or more. However, when these drysurface-resistant strains were exposed to moist copper surfaces, resistance levels were close to those of control strains. This suggested that resistance mechanisms against dry metallic copper differ from those responsible for defense against wet surfaces or dissolved copper ions. Furthermore, the investigated staphylococci did not exhibit increased levels of resistance to antibiotics [23].

Copper surfaces obtained by deposition of copper through cold spray exhibit high killing efficacy against methicillin-resistant Staphylococcus aureus (MRSA) due to the copper microstructure that enhances the ionic diffusivity [24]. Both laboratory tests and clinical trials [25] have confirmed the superior effectiveness of copper alloys in killing bacteria when compared to components made of standard materials in hospital rooms (58\% reduction in the infection rates). In vitro testing using the USA Environmental Protection Agency (EPA) approved testing protocols [26] have demonstrated the antibacterial efficacy of copper (I) oxide impregnated polymeric solid surfaces [10].

As for copper, the antimicrobial effect of silver has been known for centuries and silver is used as an antibacterial agent in different biomaterials such as urinary catheters, wound dressings and bone cement [27], [28], [29]. Also, silver has in vitro antimicrobial activity against MRSA [30].

Silver is inherently toxic to bacteria and it can inhibit bacterial growth by deactivation of membrane proteins, as $\mathrm{Ag}^{+}$can bind to the thiol groups present in proteins [31]. However, silver and in particular silver nanoparticles due to their physicochemical properties, may also cause cytotoxicity and mitochondrial damage, although more targeted studies are still required to elucidate the role of mitochondrion in silver nanoparticles-induced toxicity [32]. 
The antibacterial effects of silver and copper have led to several studies combining these two antimicrobial components. Thus, copper and silver ions in combination can inactivate Legionella pneumophila in water distribution systems [33] and multi-layer silver-copper surface films sputter-coated on polymers for urinary catheters are efficient against Pseudomonas aeruginosa biofilm formation [34]. Silver-copper alloys, best known as sterling silver (92.5 wt.\% Ag and 7.5 wt.\% $\mathrm{Cu}$ ), have been widely employed in jewelry and mint facilities, due to their superior strength conferred by the presence of copper [35]. However, copper-silver cast alloys with copper content between 50\% and 94\% [36] have only received limited attention, due to the limited solid solubility of the system $(8.8 \mathrm{wt} . \% \mathrm{Cu}$ in the silver-rich phase and $8.0 \mathrm{wt} . \% \mathrm{Ag}$ in the copper-rich phase at the eutectic point), according to the copper-silver phase diagram [37].

However, one study has demonstrated that a copper-silver alloy with 10 wt.\% Ag obtained by intermixing of copper and silver on stainless steel through laser cladding process had a higher biocidal activity against Escherichia coli as compared to the pure elements [38].

Based on the above studies, we decided to investigate the antibacterial potential of an electroplated copper-silver alloy coating. Electroplating is one of the predominant surface technologies in Europe that aim at enhancing or providing various substrates with wear and corrosion protection, electrical conductivity and self-cleaning properties. Electroplating links and comprises a number of different sectors, thus it is one of the most significant manufacturing branches in the European economy [39]. Electroplating on different low-cost bulk materials characterized by various and complicated shape is easily feasible especially in a large-scale production. In fact, a number of key industries employ electroplating for reasons of economical and/or convenience factors, although other methods such evaporation and sputtering CVD (chemical vapor deposition) are an option [40]. Moreover, this process allows a regenerative 
design approach to recycle remaining coatings by stripping processes and further electroplate the items when the coating is worn off.

The purpose of the present study was to develop an antibacterial electroplated copper-silver alloy coating for stainless steel. The coating microstructure, chemical and electrochemical nature was characterized in detail by scanning electron microscopy, energy dispersive X-ray spectrometry, X-ray diffraction analysis and potentiodynamic polarization in different electrolyte solutions. The antibacterial properties of the copper-silver alloy coating and the ion release were investigated through bacterial adhesion tests and inductively coupled plasma mass spectroscopy (ICP-MS).

\section{Materials and methods}

\subsection{Materials}

The specimens were cut into $60 \times 20 \times 1 \mathrm{~mm}$ and $10 \times 20 \times 1 \mathrm{~mm}$ size coupons from AISI 316 and AISI 316L cold rolled sheet of steel having 2B surface finish, respectively. For the corrosion studies, cylindrical shape specimens were used according to ASTM G5-14 [41]. The chemical composition of AISI 316 and AISI 316L from supplier data sheet is presented in Table I.

\subsection{Surface preparation method}

The AISI 316 and AISI 316L specimens were electroplated at a current of $4 \mathrm{~A} \mathrm{dm}^{-2}$ for $1 \mathrm{~min}$ in a commercially modified copper-silver bath at Elplatek A/S Galvanord. To achieve the desired layer thickness i.e. $10 \pm 0.8 \mu \mathrm{m}$, this process was repeated four times on each specimen. 
AISI 316L specimens were electroplated at a current of $5 \mathrm{~A} \mathrm{dm}^{-2}$ for $10 \mathrm{~min}$ in a commercial acidic copper bath and at a current of $1 \mathrm{~A} \mathrm{dm}^{-2}$ for $15 \mathrm{~min}$ in a commercial silver bath. Current density and time were chosen in order to achieve a coating thickness of $10 \pm 0.5 \mu \mathrm{m}$.

Prior to the electroplating process, the specimens were cathodically degreased in a cyanide bath keeping the voltage at $3 \pm 0.5 \mathrm{~V}$ for 2 min followed by rinsing with deionized water. After the rinsing, an activation step for the stainless steel substrate through a Wood's nickel strike was carried out at a current of $4.5 \pm 0.5 \mathrm{~A} \mathrm{dm}^{-2}$ for $2 \mathrm{~min}$ in order to ensure good adhesion between the electroplated coatings and the substrate. In the case of silver electroplating, a strike bath was performed at a current of $0.5 \mathrm{~A} \mathrm{dm}^{-2}$ for 1 min to prevent immersion deposit and poor adhesion.

\subsection{Microstructural characterization}

\subsubsection{Scanning electron microscopy and energy dispersive $X$-ray spectrometry}

The microstructure and the chemical composition of the copper-silver alloy coated specimens were analyzed by scanning electron microscopy (SEM) (JEOL JSM 5900 Instrument operated at $13 \mathrm{kV}$ ) which was equipped with Oxford EDS detector and Oxford Inca software.

\subsubsection{X-ray diffraction analysis}

The crystalline structure of the deposited layer was determined by using X-ray diffraction. Chromium radiation $\left(\mathrm{K}_{\alpha}=2.29 \AA\right)$ was chosen with a step time of $576 \mathrm{~s}$ and the scanning was performed from $32^{\circ}$ to $78^{\circ}$ values of $2 \theta$ angles with steps of $0.060^{\circ} \theta$.

\subsection{Potentiodynamic polarization}

Potentiodynamic polarization scans were recorded according to ASTM G5-14 standard test method with an ACM (GillAC) potentiostate. A saturated calomel electrode and an iridium-oxide 
coated titanium electrode were used as reference and counter electrodes, respectively. The electrolytes used for polarization scans were EN 1811 artificial sweat media $(\mathrm{NaCl} 5.00 \pm 0.01 \mathrm{~g} / \mathrm{l}$, $\mathrm{CH}_{4} \mathrm{~N}_{2} \mathrm{O} 1.00 \pm 0.01 \mathrm{~g} / \mathrm{l}, \mathrm{CH}_{3} \mathrm{CHOHCOOH} 940 \pm 20 \mu \mathrm{l}, \mathrm{DI} \mathrm{H}_{2} \mathrm{O} 900 \mathrm{ml}, \mathrm{pH} 6.5$ at $\left.19^{\circ} \mathrm{C}\right), 0.1 \mathrm{M}$ $\mathrm{Na}_{2} \mathrm{CO}_{3}$ solution and phosphate-buffered saline buffer solution (PBS; Dulbecco A; Oxoid). Prior to the polarization scans, the OCP was monitored for $24 \mathrm{~h}$. The measurements were performed on copper-silver alloy coated and AISI 316 specimens and conducted in replicas for consistency.

\subsection{Antibacterial test}

The bacterial adhesion to AISI 316L and copper-silver alloy coated coupons were tested using Staphylococcus aureus 8325 [42] and Escherichia coli MG1655 [43].

The bacterial adhesion to AISI 316L, pure copper, pure silver and copper-silver alloy electroplated coupons were tested using Staphylococcus aureus 8325 [42]

The bacteria were revived from $-80^{\circ} \mathrm{C}$ storage and grown on Brain Heart Infusion (BHI) agar plates (Oxoid, CM1135) at $25^{\circ} \mathrm{C}$ overnight. The bacteria were inoculated in BHI broth (Oxoid, $\mathrm{CM} 1135$ ) and grown for two days at $25^{\circ} \mathrm{C}$. Ten-fold serial dilutions were made and bacterial cells transferred to phosphate-buffered saline solution (PBS; Dulbecco A; Oxoid) to an initial level of approx. $10^{6} \mathrm{CFU} / \mathrm{ml}$. In the test with the four different materials $S$. aureus at an initial level of approx. $10^{7} \mathrm{CFU} / \mathrm{ml}$ was used.

The AISI 316L and copper-silver alloy coated coupons for testing with $S$. aureus and E. coli were cathodically degreased and sterilized by autoclaving. The AISI 316L, pure copper, pure silver and copper-silver alloy electroplated coupons (Fig. 1) live adherent bacteria for testing with $S$. aureus were sterilized by dry heat in order to avoid conditions for oxide formation on copper. Bacteria suspensions were added to sterile polystyrene tubes (Sterikin LDT; Bibby Sterin LDT; Stones; UK) containing the coupons and $2 \mathrm{ml}$ of phosphate-buffered saline buffer solution (PBS; 
Dulbecco A; Oxoid). The tubes were incubated at $25^{\circ} \mathrm{C}$ for $1 / 2,4$ and 24 hours. The incubation time for the test with the four different materials against $S$. aureus was $1 / 2$ hour only.

Following the incubation time, the coupons were rinsed with $2 \mathrm{ml}$ of sterile buffer solution and moved into new sterile tubes containing $2 \mathrm{ml}$ of sterile buffer solution. These tubes were sonicated for $4 \mathrm{~min}$ at $25^{\circ} \mathrm{C}(28-\mathrm{kHz}, 2 \times 150 \mathrm{~W}$ sonication bath, Delta 220, Deltasonic, Meaux, France) and vortexed at maximum speed for $15 \mathrm{~s}$ to further facilitate the detachment of bacteria from the surfaces [44]. The number of live bacteria attached on surfaces and the cell concentration in the suspension was determined by serial dilution and plating on BHI agar (Oxoid, CM1135) [45]. In order to enumerate the total number of live bacteria per unit of surface $\left(\mathrm{CFU} / \mathrm{cm}^{2}\right), \mathrm{CFU} / \mathrm{ml}^{-1}$ values were recalculated taking into account the area $\left(4 \mathrm{~cm}^{2}\right)$ and the volume of solution $(2 \mathrm{ml})$.

For S. aureus, the antimicrobial test above was also performed with an initial diluted culture of $10^{8} \mathrm{CFU} / \mathrm{ml}$ in PBS and an initial diluted culture of $10^{6} \mathrm{CFU} / \mathrm{ml}$ in growth medium, BHI.

Experiments with AISI $316 \mathrm{~L}$ and copper-silver coated coupons against $S$. aureus and E. coli included technical triplicates and all experiments were conducted in three biological replicates.

\subsection{Ion release analysis and $\mathrm{pH}$ measurement}

The instrument used to perform the ICP-MS analysis of copper and silver ion release was an ICAPq ICPMS (Thermo, Fisher Scientific GmbH, Bremen, Germany). The analysis was performed using the isotopes ${ }^{63} \mathrm{Cu}$ and ${ }^{107} \mathrm{Ag}$, respectively, and was done using KED mode with helium as cell gas. External calibration with matrix matched calibrants and internal standardization $\left({ }^{103} \mathrm{Rh}\right)$ was done for the quantification and a x100 dilution with milli-q water was carried out prior to the analysis. The bacterial (S. aureus) suspensions of PBS and BHI media where copper-silver alloy coated coupons were tested $1 / 2,4$ and 24 hours, respectively, were 0,2 
$\mu \mathrm{m}$ filtered and stored at $-20{ }^{\circ} \mathrm{C}$ prior the analysis. PBS and $\mathrm{BHI}$ sterile solutions were analyzed as controls. The $\mathrm{pH}$ measurement of the test suspensions were carried out with a Radiometer PHM 95 pH/Ion-Meter calibrated before each set of measurement.

\subsection{Statistical analysis}

Bacterial cell numbers were log transformed and the average values among the triplicates of copper-silver coated and stainless steel coupons were calculated for each testing time. Statistical significance $(P<0.05)$ of the difference between the two surfaces was tested using the $t$-test. Numbers of live bacteria attached on surfaces and suspended bacteria in the testing solutions were compared by testing for the equality of the means assuming equal or unequal variance following the $F$-test.

\section{Results and Discussion}

\subsection{Microstructural characterization}

\subsubsection{Surface morphology, composition and cross-sectional analysis of copper-silver surfaces}

The surface morphology of the copper-silver alloy coating showed a rather uniform globular microstructure characterized by a marked distributed porosity in comparison with the stainless steel AISI 316 substrate (Fig. 2), which displayed a grain morphology typical of a 2B finished steel surface [46].

The deposition of the copper-silver alloy took place on grains and grain boundaries and the coating growth showed columnar morphology while the intrinsic porosities were present in between the columns (Fig. 3). 
The presence of grooves and flat areas (marked in Figs. 3a and 3b) represents an artifact generated during the mechanical polishing of the coated surface. The cross-sectional analysis of the coating (Fig. 3c) showed that the porosities present at the coating surface did not penetrated down to steel substrate and the coating was well adherent with the steel substrate at microscopic scale. The composition of the copper-silver coating was $59 \pm 2$ wt. $\%$ of copper and $39 \pm 2$ wt. $\%$ of silver, as displayed by the surface EDS analysis (Fig. 3d).

Since the exposed area of the copper-silver alloy coating was larger with respect to a non-porous flat surface, bacteria that meet the surface would face a higher net contact with copper and silver. In fact, the surface roughness also influenced the contact killing [6] and it was demonstrated [47] that rough electroplated copper surfaces were more antibacterial than polished or rolled copper, since the release of copper ions per time was higher.

In addition, an aqueous layer could be more easily retained at the surface due to capillary forces [48] and in such wet conditions, a galvanic cell would be established between copper and silver in the electroplated deposit. Consequently, the morphological features of the copper-silver alloy coating could play a key role in its antiadhesive and antibacterial properties.

\subsubsection{Phase analysis of copper-silver surfaces}

The X-ray diffractogram of the copper-silver alloy coating detected Ag (111) and Ag (200) peaks at near $38^{\circ}$ and $45^{\circ}$ angle (blue dotted lines) (Fig. 4).

There were two characteristic peaks at $42^{\circ}$ and $49^{\circ}$ (marked by the red solid line) corresponding to the crystallographic directions of $\mathrm{Cu}(111)$ and $\mathrm{Cu}(200)$, respectively. These peaks were shifted towards lower angles in comparison with the position of the characteristic peaks of pure 
copper (marked by the red dashed line) suggesting that a certain amount of silver atoms had entered the copper crystal lattice and therefore had warped the unit cell, causing the observed shift of the diffraction peaks. The variation of the lattice parameters is estimated to approx. $2 \%$ according to the multiplying factor used by DIFFRACT.EVA software to simulate an isotropic dilatation of the crystal lattice [49].

The two elements were not expected to be soluble at room temperature according to the coppersilver phase diagram [37], however it has been reported [50] that the atomic solubility of silver atoms in bulk copper resulted of about 0.08 atom $\%$ at room temperature. Therefore, on the base of the present x-ray diffraction analysis, the copper-silver alloy coating can be defined as a homogenous mixture (alloy) of the two metals where a small amount of Ag atoms had diffused into the copper crystal structure.

\subsection{Individual thermodynamic behavior of copper and silver}

Potential-pH diagrams (Pourbaix diagrams) allowed a thermodynamic evaluation of the behavior of metals in aqueous environments at different electrochemical conditions. Here, the diagrams were calculated by means of HSC Chemistry software [51] for pure copper and pure silver in three different environments which resembled the solutions of interest: EN 1811 artificial sweat, phosphate-buffered saline buffer solution (PBS; Dulbecco A; Oxoid) (Fig. 5) and $0.1 \mathrm{M} \mathrm{Na}_{2} \mathrm{CO}_{3}$ (Fig. 6).

The purpose was to provide the experimental polarization measurements with a thermodynamic basis, which gave information about regions of metal stability, oxide formation and metal dissolution at potential and $\mathrm{pH}$ of interest. The calculated diagrams showed that around neutral $\mathrm{pH}$ conditions $7 \pm 0.5$ a protective $\mathrm{AgCl}$ layer was likely formed on silver in a chloride-containing environment above $250 \mathrm{mV}$ (Figs. 5a and 5b) and $\mathrm{Cu}$ was dissolved in the form $\mathrm{CuCl}_{2}{ }^{-}$between 
100 and $400 \mathrm{mV}$ (Figs. 5c and 5d). However, in presence of a solution containing $0.1 \mathrm{M} \mathrm{Na}_{2} \mathrm{CO}_{3}$, the $\mathrm{pH}$ raised up to 11 . Under these strong alkaline $\mathrm{pH}$ conditions at $100 \mathrm{mV}$, silver (Fig. 6a) remained in its stability region, whereas $\mathrm{Cu}_{2} \mathrm{O}$ and $\mathrm{CuO}$ formed on the copper surface (Fig. 6b). In dry environmental conditions the formation of $\mathrm{Cu}_{2} \mathrm{O}$ was favored, while in humid conditions during long aging periods $\mathrm{CuO}$ was formed [6], [10]. In addition, it was reported [52] that the presence of chloride ions shifted the formation of $\mathrm{Cu}_{2} \mathrm{O}$ to more alkaline $\mathrm{pH}$. Cuprous oxide showed the same antibacterial efficacy as pure copper, while cupric oxide exhibited much slower antibacterial killing [6], [10] and this was correlated to the higher solubility of $\mathrm{Cu}_{2} \mathrm{O}$, i.e. higher ionic release, as compared to $\mathrm{CuO}$. Therefore, this suggested that the long exposure of copper to humid atmosphere would reduce its antibacterial activity due to the formation of $\mathrm{CuO}$.

Under oxidizing conditions or at high $\mathrm{pH}$ above $500 \mathrm{mV}$ silver oxides would form and it has been suggested [6] that $\mathrm{AgO}$ was probably main responsible of observed antimicrobial effect of silver, since it has high solubility, even greater than $\mathrm{Cu}_{2} \mathrm{O}$.

\subsection{Polarization behavior of copper-silver surfaces}

The anodic behavior of AISI 316 and copper-silver alloy coating was studied in different electrolytes i.e. EN 1811 artificial sweat media, $0.1 \mathrm{M} \mathrm{Na}_{2} \mathrm{CO}_{3}$ solution and phosphate-buffered saline buffer solution (PBS), respectively (Fig. 7).

In all the electrolytes, AISI 316 displayed its typical passive nature. However, the change in the type of electrolyte shifted the corrosion potential values, i.e. $+20 \mathrm{mV}$ (vs. SHE) for artificial sweat, $-100 \mathrm{mV}$ (vs. SHE) for $0.1 \mathrm{M} \mathrm{Na}_{2} \mathrm{CO}_{3}$ and $-75 \mathrm{mV}$ (vs. SHE) for PBS. A similar phenomenon was also observed for the copper-silver alloy coating where the corrosion potential was $+80 \mathrm{mV}$ (vs. SHE) for artificial sweat, $+100 \mathrm{mV}$ (vs. SHE) for $0.1 \mathrm{M} \mathrm{Na}_{2} \mathrm{CO}_{3}$ and $+50 \mathrm{mV}$ (vs. SHE) for PBS. Overall, the corrosion potential values for copper-silver alloy coating 
exhibited higher shift towards the noble side when compared to stainless steel, regardless of electrolyte type. The copper-silver alloy coating showed active behavior by exhibiting higher values of anodic current density when compared to stainless steel surface. In contrast, the coppersilver alloy coating showed passive nature in $0.1 \mathrm{M} \mathrm{Na}_{2} \mathrm{CO}_{3}$ solution and lower anodic current density values when compared the chloride-containing environments (artificial sweat and PBS). The higher anodic current density of the copper-silver alloy coating in comparison with stainless steel was probably due to the presence of copper, which speeded up the corrosion rate. On the other hand, the copper-silver alloy coating displayed a higher corrosion potential than stainless steel and this was likely because silver possessed higher cathodic potential than stainless steel. Moreover, the natural formation of the protective chromium oxide on the stainless steel surface conferred it the typical passive nature [53].

In accordance with previous studies [54], [55] and consistent with the calculated Pourbaix diagrams (Figs. 5c and 5d), potentiodynamic polarization tests confirmed that copper dissolved from the surface of the coating in presence of a chloride-containing environments as the more toxic $\mathrm{Cu}^{+}[12]$ in the form of soluble cuprous chloride ion complex $\mathrm{CuCl}_{2}^{-}$.

Therefore, since the formation of copper oxides responsible for a passivation state was prevented in presence of chlorides at $\mathrm{pH}$ near neutrality, the corrosion rates increased in comparison with the case of $0.1 \mathrm{M} \mathrm{Na}_{2} \mathrm{CO}_{3}$ solution. In the latter case, a passivation state was likely reached due to the formation of copper oxide at potentials greater than $100 \mathrm{mV}$ (Fig. 6b).

\subsection{Bacterial adhesion and survival to copper-silver alloy coating and AISI 316L}

\subsubsection{Antibacterial effect against $S$. aureus}


S. aureus, at a level of $10^{6} \mathrm{CFU} / \mathrm{ml}$ buffer, adhered to the AISI $316 \mathrm{~L}$ coupons at a level of $10^{4}$ $\mathrm{CFU} / \mathrm{cm}^{2}$ whereas the number on the copper-silver alloy coated coupons was lower than 10 $\mathrm{CFU} / \mathrm{cm}^{2}$ (Table II).

The differences were, at all time points, statistically significant $(P=0.0001)$. The copper-silver alloy surfaces maintained its efficacy in repelling the attachment of live bacteria when the initial concentration of S. aureus culture was approx. $10^{8} \mathrm{CFU} / \mathrm{ml}$ (Table II). The difference in numbers of bacteria was, again, clearly statistically significant $(P=0.0004)$.

The antibacterial effect of the copper-silver alloy coating was less pronounced when S. aureus was allowed to grow in BHI broth during attachment. The number of live adherent bacteria on the copper-silver alloy surfaces and the AISI $316 \mathrm{~L}$ was initially approx. $10^{2}$ and $10^{3} \mathrm{CFU} / \mathrm{cm}^{2}$ respectively. The number of live adherent bacteria increased from approx. $10^{2} \mathrm{CFU} / \mathrm{cm}^{2}$ to $10^{5}$ $\mathrm{CFU} / \mathrm{cm}^{2}$ on the copper-silver alloy surfaces over 24 hours and the number on the stainless steel controls was constantly 1-2 log units above (Table II). The difference in numbers of live adherent bacteria on the two types of surfaces was not statistically significant $(P=0.522)$.

The numbers of S. aureus decreased from $10^{6} \mathrm{CFU} / \mathrm{ml}$ to $10^{2} \mathrm{CFU} / \mathrm{ml}$ in the PBS suspension in the presence of copper-silver alloy coupons whilst remaining constant where the AISI 316L coupons were immersed $(P=0.042)$ (Table III).

There was a slight decrease in S. aureus numbers in BHI broth in the presence of copper-silver alloy coated coupons as compared to the AISI 316L (Table III) but this was not statistically significant $(P=0.963)$. 
S. aureus, at an initial level of $10^{7} \mathrm{CFU} / \mathrm{ml}$ buffer, adhered to the AISI $316 \mathrm{~L}$ and silver coupons at a level of approx. $10^{5} \mathrm{CFU} / \mathrm{cm}^{2}$ whereas the number on the copper coupons was approx. $10^{3}$ $\mathrm{CFU} / \mathrm{cm}^{2}$ and on the copper-silver alloy coated coupons was lower than $10 \mathrm{CFU} / \mathrm{cm}^{2}$ after 30 minutes (Table IV). These results confirmed that metallic silver is not antibacterial in test conditions where the silver ions release is not occurring, as it can be seen from the Pourbaix diagram (Fig. 5) and as stated previously [6]. On the other hand, copper had antibacterial activity with approx. two-log reduction in S. aureus attachment compared to stainless steel. The coppersilver alloy coating had the highest antibacterial efficacy in these test conditions, with approx. a four-log reduction after 30 minutes of exposure to $S$. aureus.

\subsubsection{Antibacterial effect against E.coli}

E.coli, at a level of $10^{6} \mathrm{CFU} / \mathrm{ml}$ buffer, adhered to the AISI 316L surfaces at a level of approx. $10^{2} \mathrm{CFU} / \mathrm{cm}^{2}$ whereas the number on the copper-silver alloy coated coupons was lower than 10 $\mathrm{CFU} / \mathrm{cm}^{2}$ (Table V).

A similar investigation [38] reported in literature has demonstrated the high antibacterial activity of a $\mathrm{CuAg}$ clad alloy (with 10 wt.\% $\mathrm{Ag}$ ) against $E$. coli with six logs reduction in $180 \mathrm{~min}$ through wet plating testing [56], which was followed by pure copper (4 log reduction), silver and stainless steel that did not exhibit significant antimicrobial effect [38].

Even though the initial cell concentration was not indicated in the study [38], our results confirmed the reported findings within a six-time lower exposure time, as we observed a six logs reduction within 30 minutes. These results suggests that the killing activity of the copper-silver alloy electroplated coating may be faster than the $\mathrm{CuAg}$ clad alloy.

Besides, the study [38] addressed that the increased antimicrobial properties of the CuAg clad alloy may be primarily due to the higher release of copper ions, which in turn is governed by the 
surface electrochemistry. This also explained the faster efficacy observed in the copper-silver alloy electroplated coating, since the higher amount of silver in the coating (approx. 40 wt.\%) increased the cathodic and anodic areas ratio, which controlled the speed of the anodic reaction. Moreover, the electroplated copper-silver surface had a higher roughness (Fig. 2 and 3), which increased the bacteria-metal contact area and the release of copper ions per time [6], [47], [57].

The numbers of E.coli decreased from $10^{6} \mathrm{CFU} / \mathrm{ml}$ to approx. $10^{3} \mathrm{CFU} / \mathrm{ml}$ in the PBS suspension in the presence of copper-silver alloy coupons whilst remaining constant where the AISI $316 \mathrm{~L}$ coupons were immersed, but the difference in numbers was not statistically significant $(P=$ 0.221) (Table V).

\subsection{Ion release and $\mathrm{pH}$ variation during the bacterial adhesion tests}

Copper ion concentration in the PBS suspensions where the copper-silver alloy coated coupons were immersed with an initial concentration of $S$. aureus of approx. $10^{6} \mathrm{CFU} / \mathrm{ml}$ increased over time and reached 3,500 $\mu \mathrm{g} / \mathrm{l}$ after 24 hours (Table VI).

When the initial concentration of $S$. aureus culture was $10^{8} \mathrm{CFU} / \mathrm{ml}$, the copper ion concentration was significantly increased and reached a level of almost $88,000 \mu \mathrm{g} / \mathrm{l}$ after 24 hours. This can be attributed to the higher bacterial load but also to the media carry-over from the initial diluted bacterial suspensions.

Copper ions in aqueous solutions easily form coordination compounds with organic species such as proteins and carbohydrates, therefore medium composition and $\mathrm{pH}$ influences greatly the sensitivity of bacteria towards copper ions [58].

Under the same conditions, the release of silver ions was negligible compared to copper (Table VI) in accordance with previous results [38]. From the stainless steel controls, the release of 
copper ions was lower but in the same order of magnitude in comparison with the copper-silver alloy coated surfaces immersed in suspension with the initial concentration of $S$. aureus of approx. $10^{6} \mathrm{CFU} / \mathrm{ml}$ (Table VI). We did not expect copper ion release from the stainless steel, however copper is often added to stainless steel during the metallurgical process in order to enhance its resistance to corrosion (increase the pitting potential) [59], even if not always indicated by the supplier, as in the present case.

Copper ion concentration in the BHI suspensions with an initial concentration of $S$. aureus of approx. $10^{6} \mathrm{CFU} / \mathrm{ml}$ increased over time with values in between the concentrations measured in the PBS suspensions. In this case, the ion release increased to almost 49,000 $\mu \mathrm{g} / \mathrm{l}$ after 24 hours and the release of metal ions from the stainless steel controls was negligible (Table VI). The presence of complex medium speeded up the release of copper ions compared to the buffer solution with the same initial cell concentration (Table VI).

The $\mathrm{pH}$ increased linearly from $7.3 \pm 0.1$ to $7.7 \pm 0.1$ over the 24 hours where the copper-silver alloy coated coupons were immersed in buffer with $S$. aureus. In contrast, $\mathrm{pH}$ remained stable at about 7.3 \pm 0.1 in buffer with stainless steel surfaces emerged (Table VII).

The $\mathrm{pH}$ of the BHI suspensions were lower and no significant difference was between the copper-silver surfaces and the stainless steel was observed after $1 / 2$ hour and 4 hours (Table VII). After 24 hours, the $\mathrm{pH}$ increased in both the stainless steel and the copper-silver suspensions, but more markedly in the latter.

The concentration of copper ions increased in all the suspensions, whereas in comparison silver was released only in negligible amounts. This further indicates that in presence of a chloridecontaining environment silver is protected by the selective corrosion, i.e. dissolution, of copper induced by the galvanic coupling. The increase of $\mathrm{pH}$ in the PBS suspensions was probably due 
to the progressive precipitation of $\mathrm{CuCl}_{2}^{-}$(Figure 5c and 5d) following the overtime dissolution of copper ions. Therefore, the shift towards a more alkaline environment could add a further damaging effect to the biocidal action of the copper ions.

The charged amino acids of the meat extracts in BHI, acting as cation "sink," could have reduced the amount of free ions accessible to bacteria and the ions complexation could have also maintained the $\mathrm{pH}$ of the suspension more stable to lower values, protecting in this way the bacteria in their growing environment [60].

\section{Conclusions}

In this study, an electroplated copper-silver alloy coating was developed and characterized in its microstructure, chemical and electrochemical nature. The copper-silver alloy coating (59 $\pm 2 \mathrm{wt}$. $\% \mathrm{Cu}$ and $39 \pm 2$ wt. \% Ag) had a significant antibacterial effect against $S$. aureus and E. coli as compared to AISI $316 \mathrm{~L}$ stainless steel. The coating was also superior in antibacterial activity against $S$. aureus when compared to pure copper electroplated surfaces.

The electrochemical mechanism, the copper and silver areas ratio and the porous microstructure were believed responsible. In presence of a chloride-containing environment, bacteria would be exposed to metallic copper at the interface, $\mathrm{Cu}^{+}$ions in the surroundings and metallic silver where the $\mathrm{pH}$ raises locally. Therefore, the galvanic coupling would allow the copper-silver alloy electroplated coating to maintain its antibacterial efficiency in the intended working conditions. The electroplated copper-silver alloy coating could therefore be an effective coating solution for reasons of economy and convenience in the burdensome struggle against the proliferation and transmission of pathogens in hospitals and intensive care units. However, further investigations are required to assess the behavior of the coating in dry environmental conditions and the kinetics of the bacterial inactivation. 


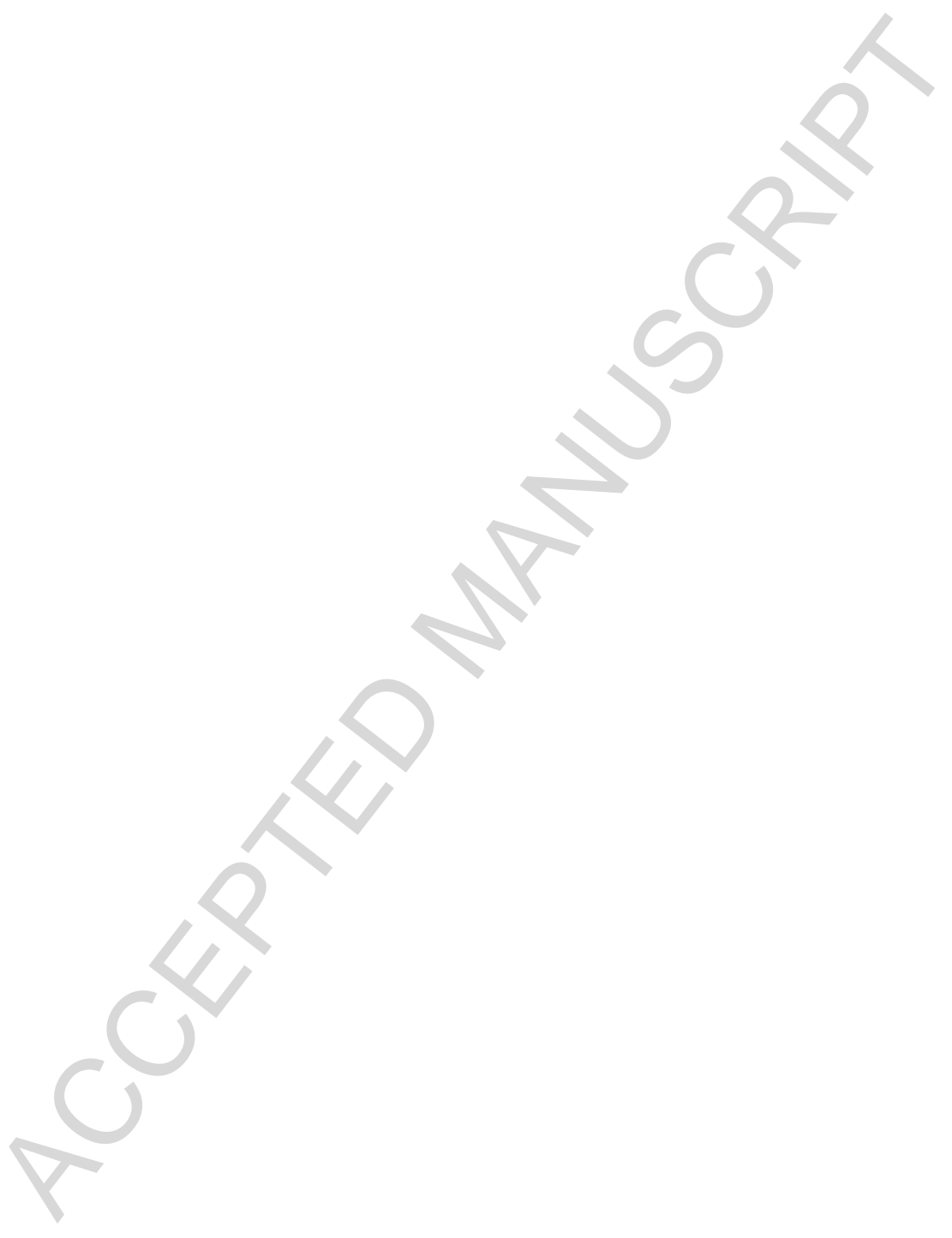




\section{Acknowledgements}

We thank Yin Ng and Jette Melchiorsen for work on the antimicrobial testing, Flemming Bjerg Grumsen for assisting during the X-ray diffraction analysis and Birgitte Koch Herberg for work on the ICP-MS analysis. In addition, we thank Professor Jens Duus and Betina Margrethe Farrington Roesdahl for help on the chemical analysis.

Funding: This work was supported by the Innovation Fund of Denmark (case nr. 5189-00091B).

\section{References}

[1] WHO, Report on the Burden of Endemic Health Care-Associated Infection Worldwide Clean Care is Safer Care, 2011.

[2] European Centre for Disease Prevention and Control, Point Prevalence Survey of Healthcare-Associated Infections and Antimicrobial Use in European Hospitals 20112012, Stockholm, 2013.

[3] European Centre for Disease Prevention and Control, Annual Epidemiological Report 2016 - Healthcare-associated infections acquired in intensive care units., Stockholm, 2016.

[4] European Centre for Disease Prevention and Control, Healthcare-associated infections acquired in intensive care units. Annual epidemiological report for 2015, Stockholm, 2017.

[5] J.M. Boyce, Environmental contamination makes an important contribution to hospital infection, J. Hosp. Infect. 65, Supple (2007) 50-54. doi:http://dx.doi.org/10.1016/S01956701(07)60015-2.

[6] M. Hans, S. Mathews, F. Mücklich, M. Solioz, Physicochemical properties of copper 
important for its antibacterial activity and development of a unified model, Biointerphases. 11 (2016) 18902. doi:10.1116/1.4935853.

[7] G. Grass, C. Rensing, M. Solioz, Metallic copper as an antimicrobial surface, Appl. Environ. Microbiol. 77 (2011) 1541-1547. doi:10.1128/AEM.02766-10.

[8] J.A. Lemire, J.J. Harrison, R.J. Turner, Antimicrobial activity of metals: mechanisms, molecular targets and applications, Nat. Rev. Microbiol. 11 (2013) 371-384. doi:10.1038/nrmicro3028.

[9] C.D. Salgado, K.A. Sepkowitz, J.F. John, J.R. Cantey, H.H. Attaway, K.D. Freeman, P.A. Sharpe, H.T. Michels, M.G. Schmidt, Copper surfaces reduce the rate of healthcareacquired infections in the intensive care unit., Infect. Control Hosp. Epidemiol. 34 (2013). doi:10.1086/670207.

[10] M. Hans, A. Erbe, S. Mathews, Y. Chen, M. Solioz, F. Mücklich, Role of copper oxides in contact killing of bacteria, Langmuir. 29 (2013) 16160-16166. doi:10.1021/1a404091z.

[11] A.B. Monk, V. Kanmukhla, K. Trinder, G. Borkow, Potent bactericidal efficacy of copper oxide impregnated non-porous solid surfaces., BMC Microbiol. 14 (2014) 57. doi:10.1186/1471-2180-14-57.

[12] H.K. Abicht, Y. Gonskikh, S.D. Gerber, M. Solioz, Non-enzymic copper reduction by menaquinone enhances copper toxicity in Lactococcus lactis IL1403, Microbiol. (United Kingdom). 159 (2013) 1190-1197. doi:10.1099/mic.0.066928-0.

[13] C.E. Santo, N. Taudte, D.H. Nies, G. Grass, Contribution of copper ion resistance to survival of Escherichia coli on metallic copper surfaces, Appl. Environ. Microbiol. 74 (2008) 977-986. doi:10.1128/AEM.01938-07. 
[14] C.E. Santo, E.W. Lam, C.G. Elowsky, D. Quaranta, D.W. Domaille, C.J. Chang, G. Grass, Bacterial killing by dry metallic copper surfaces, Appl. Environ. Microbiol. 77 (2011) 794-802. doi:10.1128/AEM.01599-10.

[15] M. Zeiger, M. Solioz, H. Edongué, E. Arzt, A.S. Schneider, Surface structure influences contact killing of bacteria by copper., Microbiologyopen. 3 (2014) 327-32. doi:10.1002/mbo3.170.

[16] L. Macomber, C. Rensing, J.A. Imlay, Intracellular Copper Does Not Catalyze the Formation of Oxidative DNA Damage in Escherichia coli, J. Bacteriol. 189 (2007) 16161626. doi:10.1128/JB.01357-06.

[17] U.S. Department of Health and Human Services, Toxicological profile for Copper, 2004. doi:10.1201/9781420061888_ch106.

[18] A. Dorsey, L. Ingerman, S. Swarts, Relevance To Public Health Background and Environmental Exposures To Copper in the United States, Agency Toxic Subst. Dis. Regist. (2004) 11-19. http://www.atsdr.cdc.gov/toxprofiles/tp132.pdf.

[19] R. Uauy, A. Maass, M. Araya, Estimating risk from copper excess in human populations, Am. J. Clin. Nutr. 88 (2008) 867-871. doi:88/3/867S [pii].

[20] R.J.G. Rycroft, T. Menne, P.J. Frosch, J.-P. Lepoittevin, Textbook of Contact Dermatitis, 3rd ed., Springer-Verlag Berlin Heidelberg, 1995. doi:10.1007/978-3-662-10302-9.

[21] N.A. Vashi, A. Souza, N. Cohen, B. Franklin, D.E. Cohen, Allergic contact dermatitis caused by methylphenidate, Contact Dermatitis. 65 (2011) 183-185. doi:10.1111/j.16000536.2011.01949.x. 
[22] K.E. Olive, Numismedica: Health Problems Caused by Coins, Am. J. Med. Sci. 337 (2017) 445-450. doi:10.1097/MAJ.0b013e31819e8791.

[23] C.E. Santo, P.V. Morais, G. Grass, Isolation and characterization of bacteria resistant to metallic copper surfaces, Appl. Environ. Microbiol. 76 (2010) 1341-1348. doi:10.1128/AEM.01952-09.

[24] V.K. Champagne, D.J. Helfritch, A demonstration of the antimicrobial effectiveness of various copper surfaces., J. Biol. Eng. 7 (2013) 8. doi:10.1186/1754-1611-7-8.

[25] H.T. Michels, C.W. Keevil, C.D. Salgado, M.G. Schmidt, From Laboratory Research to a Clinical Trial: Copper Alloy Surfaces Kill Bacteria and Reduce Hospital-Acquired Infections, HERD Heal. Environ. Res. Des. J. 9 (2015) 64-79. doi:10.1177/1937586715592650.

[26] H.T. Michels, D.G. Anderson, Antimicrobial regulatory efficacy testing of solid copper alloy surfaces in the USA, Met. Ions Biol. Med. 10 (2008) 185-190. doi:10.1016/j.jval.2013.08.181.

[27] P. Khalilpour, K. Lampe, M. Wagener, B. Stigler, C. Heiss, M.S. Ullrich, E. Domann, R. Schnettler, V. Alt, Ag/SiOxCy plasma polymer coating for antimicrobial protection of fracture fixation devices, J. Biomed. Mater. Res. - Part B Appl. Biomater. 94 (2010) 196202. doi:10.1002/jbm.b.31641.

[28] A.B.G. Lansdown, A. Williams, S. Chandler, S. Benfield, Silver absorption and antibacterial efficacy of silver dressings, J. Wound Care. 14 (2005) 155-160. doi:10.12968/jowc.2005.14.4.26762.

[29] T. Bechert, M. Böswald, S. Lugauer, A. Regenfus, J. Greil, J.-P. Guggenbichler, The 
erlanger silver catheter:In vitro results for antimicrobial activity, Infection. 27 (1999) S24-S29. doi:10.1007/BF02561613.

[30] V. Alt, T. Bechert, P. Steinrücke, M. Wagener, P. Seidel, E. Dingeldein, E. Domann, R. Schnettler, An in vitro assessment of the antibacterial properties and cytotoxicity of nanoparticulate silver bone cement, Biomaterials. 25 (2004) 4383-4391. doi:10.1016/j.biomaterials.2003.10.078.

[31] T.C. Dakal, A. Kumar, R.S. Majumdar, V. Yadav, Mechanistic Basis of Antimicrobial Actions of Silver Nanoparticles, 7 (2016) 1-17. doi:10.3389/fmicb.2016.01831.

[32] L.L. Maurer, J.N. Meyer, A systematic review of evidence for silver nanoparticle-induced mitochondrial toxicity, Environ. Sci. Nano. 3 (2016) 311-322. doi:10.1039/C5EN00187K.

[33] Y.-S.E. Lin, R.D. Vidic, J.E. Stout, V.L. Yu, Individual and combined effects of copper and silver ions on inactivation of Legionella pneumophila, Water Res. 30 (1996) 19051913. doi:10.1016/0043-1354(96)00077-2.

[34] R.J.C. McLean, A.A. Hussain, M. Sayer, P.J. Vincent, D.J. Hughes, T.J.N. Smith, Antibacterial activity of multilayer silver-copper surface films on catheter material, Can. J. Microbiol. 39 (1993) 895-899. doi:10.1139/m93-134.

[35] J.S. Sheff, Patent US2734823 - Sterling silver alloy, 1956.

[36] J. Jeffers, E.G. Bonkoungou, Copper and Copper Alloys, (2001) 75700. doi:10.1097/00000433-198206000-00020.

[37] T.B. Massalski, H. Okamoto, Binary Alloy Phase Diagrams, 2nd ed., 1990.

[38] M. Hans, J.C. Támara, S. Mathews, B. Bax, A. Hegetschweiler, R. Kautenburger, M. 
Solioz, F. Mücklich, Laser cladding of stainless steel with a copper-silver alloy to generate surfaces of high antimicrobial activity, Appl. Surf. Sci. 320 (2014) 195-199. doi:10.1016/j.apsusc.2014.09.069.

[39] European association of Surface Finishing CETS Greenovate! Europe, German Central association of Surface Finishing ZVO, Recommendation for an efficient contribution of SME companies to greater resource efficiency within the supply chain of metal finishing by focusing on interdisciplinary branches like surface finishing, 2011.

[40] M. Schlesinger, M. Paunovic, Modern electroplating, John Wiley \& Sons, 2011.

[41] ASTM G5-14 Standard Reference Test Method for Making Potentiodynamic Anodic Polarization Measurements, (2014) 1-8. doi:10.1520/G0005-13E02.2.

[42] R. Novick, Properties of a cryptic high-frequency transducing phage in Staphylococcus aureus, Virology. 33 (1967) 155-166. doi:10.1016/0042-6822(67)90105-5.

[43] B.J. Bachmann, Pedigrees of some mutant strains of Escherichia coli K-12, Bacteriol Rev. 36 (1972) 525-557.

[44] A. Asséré, N. Oulahal, B. Carpentier, Comparative evaluation of methods for counting surviving biofilm cells adhering to a polyvinyl chloride surface exposed to chlorine or drying, J. Appl. Microbiol. 104 (2008) 1692-1702. doi:10.1111/j.13652672.2007.03711.x.

[45] N. Bernbom, R.L. Jørgensen, Y.Y. Ng, R.L. Meyer, P. Kingshott, R.M. Vejborg, P. Klemm, F. Besenbacher, L. Gram, Bacterial adhesion to stainless steel is reduced by aqueous fish extract coatings, Biofilms. 3 (2006) 25-36.

doi:10.1017/S1479050507002104. 
[46] M. Hočevar, M. Jenko, M. Godec, D. Drobne, An overview of the influence of stainlesssteel surface properties on bacterial adhesion, Mater. Tehnol. 48 (2014) 609-617.

[47] M. Zeiger, M. Solioz, H. Edongué, E. Arzt, A.S. Schneider, Surface structure influences contact killing of bacteria by copper, Microbiologyopen. 3 (2014) 327-332. doi:10.1002/mbo3.170.

[48] Y.I. Rabinovich, J.J. Adler, M.S. Esayanur, A. Ata, R.K. Singh, B.M. Moudgil, Capillary forces between surfaces with nanoscale roughness, Adv. Colloid Interface Sci. 96 (2002) 213-230. doi:https://doi.org/10.1016/S0001-8686(01)00082-3.

[49] S. Graulis, D. Chateigner, R.T. Downs, A.F.T. Yokochi, M. Quirós, L. Lutterotti, E. Manakova, J. Butkus, P. Moeck, A. Le Bail, Crystallography Open Database - An openaccess collection of crystal structures, J. Appl. Crystallogr. 42 (2009) 726-729. doi:10.1107/S0021889809016690.

[50] M. Jun Kim, H. June Lee, S. Heon Yong, O. Joong Kwon, S.-K. Kim, J. Jeong Kim, Facile Formation of $\mathrm{Cu}-\mathrm{Ag}$ Film by Electrodeposition for the Oxidation-Resistive Metal Interconnect, J. Electrochem. Soc. 159 (2012) D253. doi:10.1149/2.104204jes.

[51] Outotech, HSC Chemistry, (2016).

[52] H.Y.H. Chan, C.G. Takoudis, M.J. Weaver, Oxide film formation and oxygen adsorption on copper in aqueous media as probed by surface-enhanced Raman spectroscopy, J. Phys. Chem. B. 103 (1999) 357-365. doi:10.1021/jp983787c.

[53] C.-C. Shih, C.-M. Shih, Y.-Y. Su, L.H.J. Su, M.-S. Chang, S.-J. Lin, Effect of surface oxide properties on corrosion resistance of $316 \mathrm{~L}$ stainless steel for biomedical applications, Corros. Sci. 46 (2004) 427-441. doi:10.1016/S0010-938X(03)00148-3. 
[54] D. Tromans, Anodic Polarization Behavior of Copper in Aqueous Chloride/Benzotriazole Solutions, J. Electrochem. Soc. 138 (1991) 3235. doi:10.1149/1.2085397.

[55] A.M. Alfantazi, T.M. Ahmed, D. Tromans, Corrosion behavior of copper alloys in chloride media, Mater. Des. 30 (2009) 2425-2430. doi:10.1016/j.matdes.2008.10.015.

[56] S.A. Wilks, H. Michels, C.W. Keevil, The survival of Escherichia coli $\{\mathrm{O} 157\}$ on a range of metal surfaces, Int. J. Food Microbiol. 105 (2005) 445-454. doi:https://doi.org/10.1016/j.ijfoodmicro.2005.04.021.

[57] S. Mathews, M. Hans, F. Mücklich, M. Solioz, Contact killing of bacteria on copper is suppressed if bacterial-metal contact is prevented and is induced on iron by copper ions, Appl. Environ. Microbiol. 79 (2013) 2605-2611. doi:10.1128/AEM.03608-12.

[58] H. Hasman, M.J. Bjerrum, L.E. Christiansen, H. Christian, B. Hansen, F.M. Aarestrup, The effect of $\mathrm{pH}$ and storage on copper speciation and bacterial growth in complex growth media, J. Microbiol. Methods. 78 (2009) 20-24. doi:10.1016/j.mimet.2009.03.008.

[59] C.Q. Jessen, Stainless Steel and Corrosion, 1st ed., 2011.

[60] G. Faúndez, M. Troncoso, P. Navarrete, G. Figueroa, Antimicrobial activity of copper surfaces against suspensions of Salmonella enterica and Campylobacter jejuni, 7 (2004) $1-7$. 


\section{Tables}

Table I. The chemical composition of AISI 316 and AISI 316L from the supplier (LGM) data sheet.

\begin{tabular}{ccccccc}
\hline EN10088-0 & W.nr. & ASTM & C. \% Max & Cr. \% & Ni. \% & Mo. \% \\
\hline X5CrNiMo17-12-2 & 1.4401 & 316 & 0.07 & $16.50-18.50$ & $10.00-13.00$ & $2.00-2.50$ \\
X2CrNiMo17-12-2 & 1.4404 & $316 \mathrm{~L}$ & 0.03 & $16.50-18.50$ & $10.00-13.00$ & $2.00-2.50$
\end{tabular}


Table II. Attachment of $S$. aureus to copper-silver alloy coated and uncoated stainless steel AISI 316L surfaces. Numbers are mean values \pm standard deviations of six total biological replicates performed in two technical replicates. $\mathrm{LOD}=$ limit of detection $(1 \mathrm{CFU})$.

\begin{tabular}{|c|c|c|c|c|}
\hline \multirow{2}{*}{$\begin{array}{c}\text { Dilution } \\
\text { media }\end{array}$} & \multirow{2}{*}{$\begin{array}{c}\text { Average } \\
\text { initial cell } \\
\text { concentration } \\
\log (\mathrm{CFU} \\
\left.\mathrm{ml}^{-1}\right)\end{array}$} & \multirow[b]{2}{*}{$\begin{array}{c}\text { Time } \\
\text { (h) }\end{array}$} & \multicolumn{2}{|c|}{ Attachment $\left(\log \left(\mathrm{CFU} \mathrm{cm} \mathrm{cm}^{-2}\right)\right)$ of $S$. aureus } \\
\hline & & & copper-silver & $316 \mathrm{~L}$ \\
\hline \multirow{3}{*}{ PBS } & \multirow{3}{*}{$6.3 \pm 0.5$} & 0.5 & $0.7 \pm 1.0$ & $3.9 \pm 0.1$ \\
\hline & & 4 & $<\mathrm{LOD}$ & $4.4 \pm 0.1$ \\
\hline & & 24 & $<\mathrm{LOD}$ & $4.1 \pm 0.0$ \\
\hline \multirow{3}{*}{ PBS } & \multirow{3}{*}{$8.1 \pm 0.3$} & 0.5 & $0.7 \pm 0.5$ & $4.9 \pm 0.2$ \\
\hline & & 4 & $0.3 \pm 0.4$ & $5.8 \pm 0.1$ \\
\hline & & 24 & $0.1 \pm 0.2$ & $6.5 \pm 0.2$ \\
\hline \multirow{3}{*}{$\begin{array}{l}\text { BHI } \\
\text { broth }\end{array}$} & \multirow{3}{*}{$6.6 \pm 0.1$} & 0.5 & $2.5 \pm 0.4$ & $3.2 \pm 0.2$ \\
\hline & & & $2.6 \pm 1.1$ & $4.1 \pm 0.0$ \\
\hline & & & $5.8 \pm 0.3$ & $6.8 \pm 0.3$ \\
\hline
\end{tabular}


Table III. Survival of S. aureus in suspension with copper-silver alloy coated and uncoated stainless steel AISI 316L surfaces. Numbers are mean values \pm standard deviations of three biological replicates each performed in two technical replicates. ${ }^{*}$ Only three replicates were considered. $\mathrm{LOD}=$ limit of detection $(1 \mathrm{CFU})$.

\begin{tabular}{|c|c|c|c|c|}
\hline \multirow{2}{*}{$\begin{array}{l}\text { Dilution } \\
\text { media }\end{array}$} & \multirow{2}{*}{$\begin{array}{c}\text { Average } \\
\text { initial cell } \\
\text { concentration } \\
\text { Log }(\mathrm{CFU} \\
\left.\mathrm{ml}^{-1}\right) \\
\end{array}$} & \multirow[b]{2}{*}{$\begin{array}{l}\text { Time } \\
(\mathrm{h})\end{array}$} & \multicolumn{2}{|c|}{ Survival $\log \left(\mathrm{CFU} \mathrm{ml}{ }^{-1}\right)$ of $S$. aureus in suspension } \\
\hline & & & copper-silver & AISI 316L \\
\hline \multirow{3}{*}{ PBS } & \multirow{3}{*}{$6.3 \pm 0.5$} & 0.5 & $3.6 \pm 2.9$ & $6.4 \pm 0.0$ \\
\hline & & 4 & $0.8 \pm 1.1$ & $6.2 \pm 0.0$ \\
\hline & & 24 & $0.9 \pm 1.3$ & $5.8 \pm 0.1$ \\
\hline \multirow{3}{*}{ PBS } & \multirow{3}{*}{$8.1 \pm 0.3$} & 0.5 & $6.7 \pm 0.5$ & $7.6 \pm 0.1$ \\
\hline & & 4 & $3.5 \pm 1.0$ & $7.3 \pm 0.6$ \\
\hline & & 24 & $2.0 \pm 0.3$ & $8.0 \pm 0.1$ \\
\hline \multirow{3}{*}{$\begin{array}{l}\text { BHI } \\
\text { broth }\end{array}$} & \multirow{3}{*}{$6.6 \pm 0.1$} & & $6.6 \pm 0.1$ & $6.5 \pm 0.0$ \\
\hline & & & $7.2 \pm 0.2^{*}$ & $6.7 \pm 0.6$ \\
\hline & & 24 & $8.6 \pm 0.1$ & $9.3 \pm 0.1$ \\
\hline
\end{tabular}


Table IV. Attachment of S. aureus to pure copper, pure silver, copper-silver alloy electroplated and uncoated stainless steel AISI 316L surfaces. Numbers are mean values \pm standard deviations of three biological replicates.

\begin{tabular}{|c|c|c|c|c|}
\hline \multirow{2}{*}{$\begin{array}{c}\text { Initial cell } \\
\text { concentration } \\
\log \left(\mathrm{CFU} \mathrm{ml} \mathrm{ml}^{-1}\right)\end{array}$} & \multirow{2}{*}{ Time (h) } & \multicolumn{3}{|c|}{ Attachment $\left(\log \left(\mathrm{CFU} \mathrm{cm} \mathrm{cm}^{-2}\right)\right)$ of $S$. aureus } \\
\hline & & AISI 316L & copper & copper-silver \\
\hline 7.3 & 0.5 & $4.7 \pm 0.1$ & $2.5 \pm 0.7$ & $0.1 \pm 0.1$ \\
\hline
\end{tabular}


Table V. Attachment of E. coli to copper-silver alloy coated and uncoated stainless steel AISI 316L surfaces and survival in suspension. The average initial cell concentration was 5.8 Log $\left(\mathrm{CFU} \mathrm{ml}{ }^{-1}\right)$. Numbers are mean values \pm standard deviations of three biological replicates. $\mathrm{LOD}=$

Attachment and survival of E. coli on surfaces and in suspension

\begin{tabular}{|c|c|c|c|c|}
\hline \multirow[b]{2}{*}{ Time (h) } & \multicolumn{4}{|c|}{ copper-silver } \\
\hline & $\begin{array}{c}\text { Adhesion } \\
\log \left(\mathrm{CFU} \mathrm{cm} \mathrm{cm}^{-2}\right)\end{array}$ & $\begin{array}{c}\text { Suspension } \\
\left.\log _{(\mathrm{CFU} \mathrm{ml}}{ }^{-1}\right)\end{array}$ & $\begin{array}{c}\text { Adhesion } \\
\log \left(\text { CFU cm }{ }^{-2}\right)\end{array}$ & $\begin{array}{c}\text { Suspension } \\
\log \left(\mathrm{CFU} \mathrm{ml} \mathrm{m}^{-1}\right)\end{array}$ \\
\hline 0.5 & $<\mathrm{LOD}$ & $5.6 \pm 0.1$ & 0.5 & $5.6 \pm 0.0$ \\
\hline 4 & $<\mathrm{LOD}$ & $4.6 \pm 0.2$ & $2.7 \pm 0.2$ & $5.7 \pm 0.0$ \\
\hline 24 & $<\mathrm{LOD}$ & $3.4 \pm 0.7$ & $2.5 \pm 0.4$ & $5.0 \pm 0.3$ \\
\hline
\end{tabular}

limit of detection (1 CFU). 
Table VI. Copper and silver ion concentrations released in PBS and BHI by the copper-silver alloy electroplated surfaces and the stainless steel controls at the different times measured by ICP-MS. Sterile (PBS and BHI) and filtered media that had been in contact only with bacteria were also tested as further controls.

\begin{tabular}{|c|c|c|c|c|c|c|c|}
\hline \multirow[t]{2}{*}{ Material } & \multirow{2}{*}{$\begin{array}{c}\text { Average } \\
\text { initial cell } \\
\text { concentration } \\
\text { Log }(\mathrm{CFU} \mathrm{ml} \\
\left.1^{-}\right)\end{array}$} & \multicolumn{6}{|c|}{ Metal ions concentration $\left[\mu \mathrm{g} \cdot \mathrm{l}^{-1}\right]$} \\
\hline & & $\mathrm{Cu}$ & $\mathrm{Ag}$ & $\mathrm{Cu}$ & $\mathrm{Ag}$ & $\mathrm{Cu}$ & $\mathrm{Ag}$ \\
\hline Copper-silver & & 3041 & 9 & 3108 & 15 & 3539 & 11 \\
\hline AISI 316L & & 1749 & $<5$ & 2168 & $<5$ & 3236 & 13 \\
\hline PBS filtered & & & & & & 220 & $<5$ \\
\hline PBS sterile & & & & & & 169 & $<5$ \\
\hline Copper-silver & & & 29 & 87954 & 70 & 87789 & 31 \\
\hline AISI 316L & & & $<5$ & 3567 & $<5$ & 3931 & $<5$ \\
\hline PBS filtered & & & & & & 387 & $<5$ \\
\hline PBS sterile & & & & & & 174 & $<5$ \\
\hline Copper-silver & & 94 & 7 & 41201 & 13 & 48648 & 26 \\
\hline AISI 316L & & $<10$ & 0 & 139 & $<5$ & $<10$ & $<5$ \\
\hline BHI filtered & & & & & & $<10$ & $<5$ \\
\hline BHI sterile & & & & & & $<10$ & $<5$ \\
\hline
\end{tabular}


Table VII. Values of pH measured in PBS and BHI where the copper-silver alloy electroplated surfaces and the stainless steel controls were tested at the different times. The $\mathrm{pH}$ was also measured in sterile (PBS and BHI) and filtered media that had been in contact only with bacteria.

\begin{tabular}{|c|c|c|c|c|}
\hline Material & $\begin{array}{l}\text { Average initial cell } \\
\text { concentration Log } \\
\left.\quad(\mathrm{CFU} \mathrm{ml})^{-1}\right)\end{array}$ & after $1 / 2$ hour & $\begin{array}{c}\mathrm{pH} \\
\text { after } 4 \\
\text { hours } \\
\end{array}$ & $\begin{array}{c}\text { after } 24 \\
\text { hours }\end{array}$ \\
\hline Copper-silver & & $7.3 \pm 0.1$ & $7.5 \pm 0.1$ & $7.7 \pm 0.1$ \\
\hline AISI 316L & & $7.3 \pm 0.1$ & $7.3 \pm 0.1$ & $7.3 \pm 0.1$ \\
\hline PBS filtered & $6.3 \pm 0$. & & & $7.2 \pm 0.1$ \\
\hline PBS sterile & & & & $7.2 \pm 0.1$ \\
\hline Copper-silver & & $2 \pm 0.1$ & $7.3 \pm 0.1$ & $7.7 \pm 0.1$ \\
\hline AISI 316L & & \pm 0.1 & $7.2 \pm 0.1$ & $7.2 \pm 0.1$ \\
\hline PBS filtered & & & & $7.2 \pm 0.1$ \\
\hline PBS sterile & & & & $7.2 \pm 0.1$ \\
\hline Copper-silver & & $6.1 \pm 0.1$ & $6.1 \pm 0.1$ & $6.5 \pm 0.1$ \\
\hline AISI 316L & & $6.1 \pm 0.1$ & $6.1 \pm 0.1$ & $6.2 \pm 0.1$ \\
\hline BHI filtered & & & & $6.1 \pm 0.1$ \\
\hline BHI sterile & & & & $6.9 \pm 0.1$ \\
\hline
\end{tabular}




\section{List of figure captions}

Fig. 1. From left to right: copper electroplated coupon, silver electroplated coupon, AISI 316L coupon and copper-silver alloy electroplated coupon after sterilization by dry heat.

Fig. 2. Scanning electron microscopy of uncoated (a) and copper-silver coated (b) AISI 316 at $2000 \times$ magnification.

Fig. 3. Scanning electron microscopy of copper-silver coating. The same area was captured at different magnifications: 4000× (a) and 6000× (b). Cross-section of the copper-silver coating electroplated on AISI 316 substrate (1000× magnification) (c). Scanning electron microscopy and energy dispersive $x$-ray spectrometry on the inspected copper-silver coated plate (d).

Fig. 4. XRD diffractogram of copper-silver coating. $\mathrm{Cu}$ (111) and (200) peaks were marked by a red solid line, instead the $\mathrm{Cu}(111)$ and (200) peaks representative of pure $\mathrm{Cu}$ were marked with a dashed red line. Ag (111) and (200) peaks were marked with a blue dotted line [49].

Fig. 5. Pourbaix diagrams (E-pH) of (a), (b) pure silver and (c), (d) pure copper $\left(\mathrm{Cl}^{-} \mathrm{H}_{2} \mathrm{O}\right.$ system at $25^{\circ} \mathrm{C}$ ) in the presence of $5 \mathrm{~g} / \mathrm{l}$ of $\mathrm{NaCl}$ correspondent to the artificial sweat solution (a), (c) and $8 \mathrm{~g} / \mathrm{l}$ of $\mathrm{NaCl}$ correspondent to phosphate-buffered saline buffer solution (b), (d).

Fig. 6. Pourbaix diagrams $(\mathrm{E}-\mathrm{pH})$ of (a) pure silver and (b) pure copper $\left(\mathrm{Cl}^{-} \mathrm{H}_{2} \mathrm{O}\right.$ system at 25 ${ }^{\circ} \mathrm{C}$ ) in the presence of $0.1 \mathrm{M} \mathrm{Na}_{2} \mathrm{CO}_{3}$ solution.

Fig. 7. Polarization curves of copper-silver coated AISI 316 and AISI 316 specimens tested in EN 1811 artificial sweat, and $0.1 \mathrm{M} \mathrm{Na} \mathrm{CO}_{3}$ solution and phosphate-buffered saline buffer solution. Potential $(\mathrm{mV})$ values in ordinate are recalculated against the standard hydrogen electrode (SHE). 


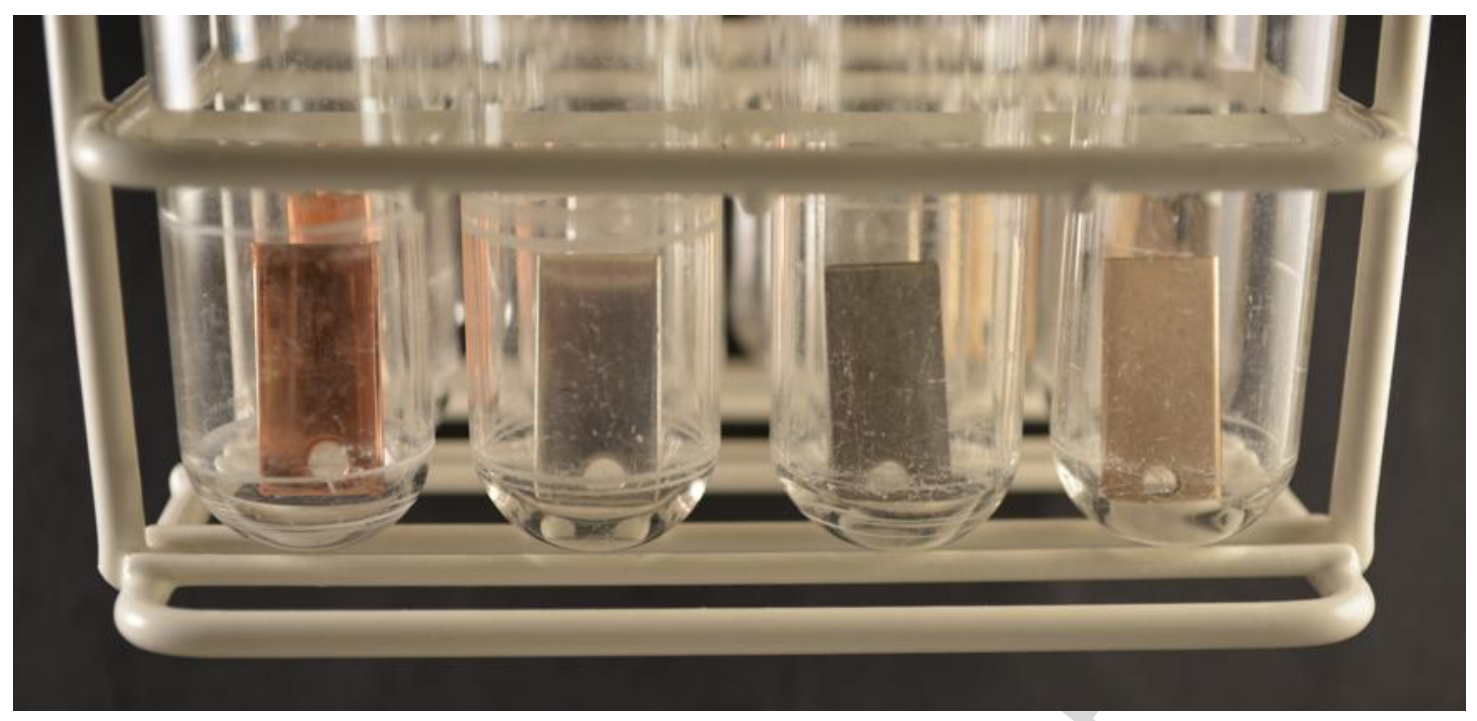

Fig. 1

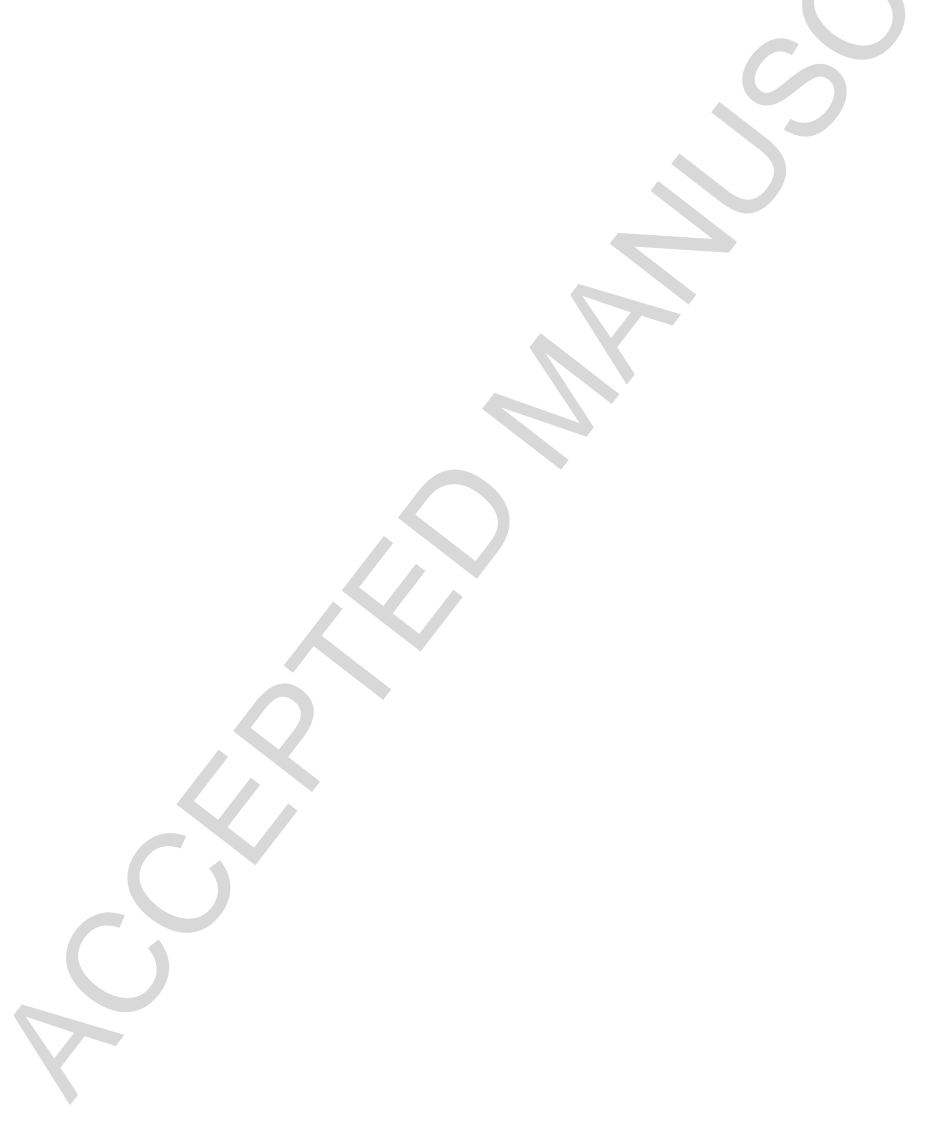



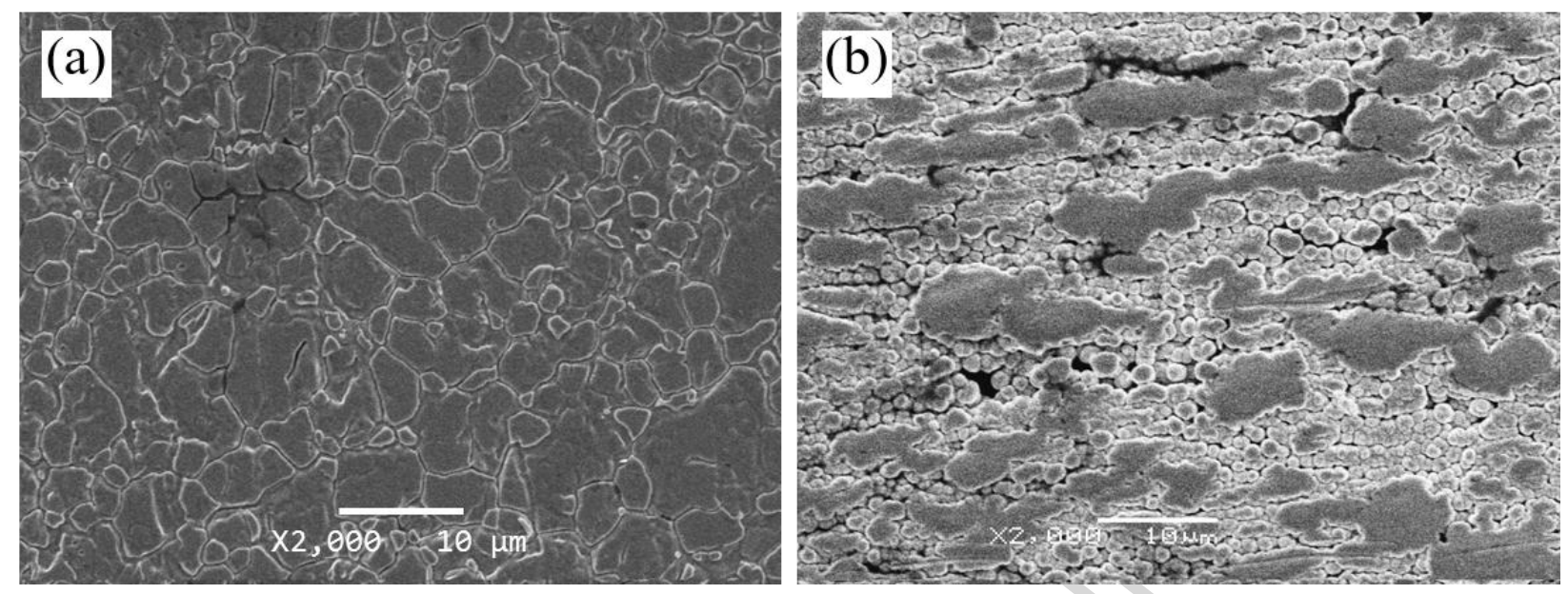

Fig. 2. 

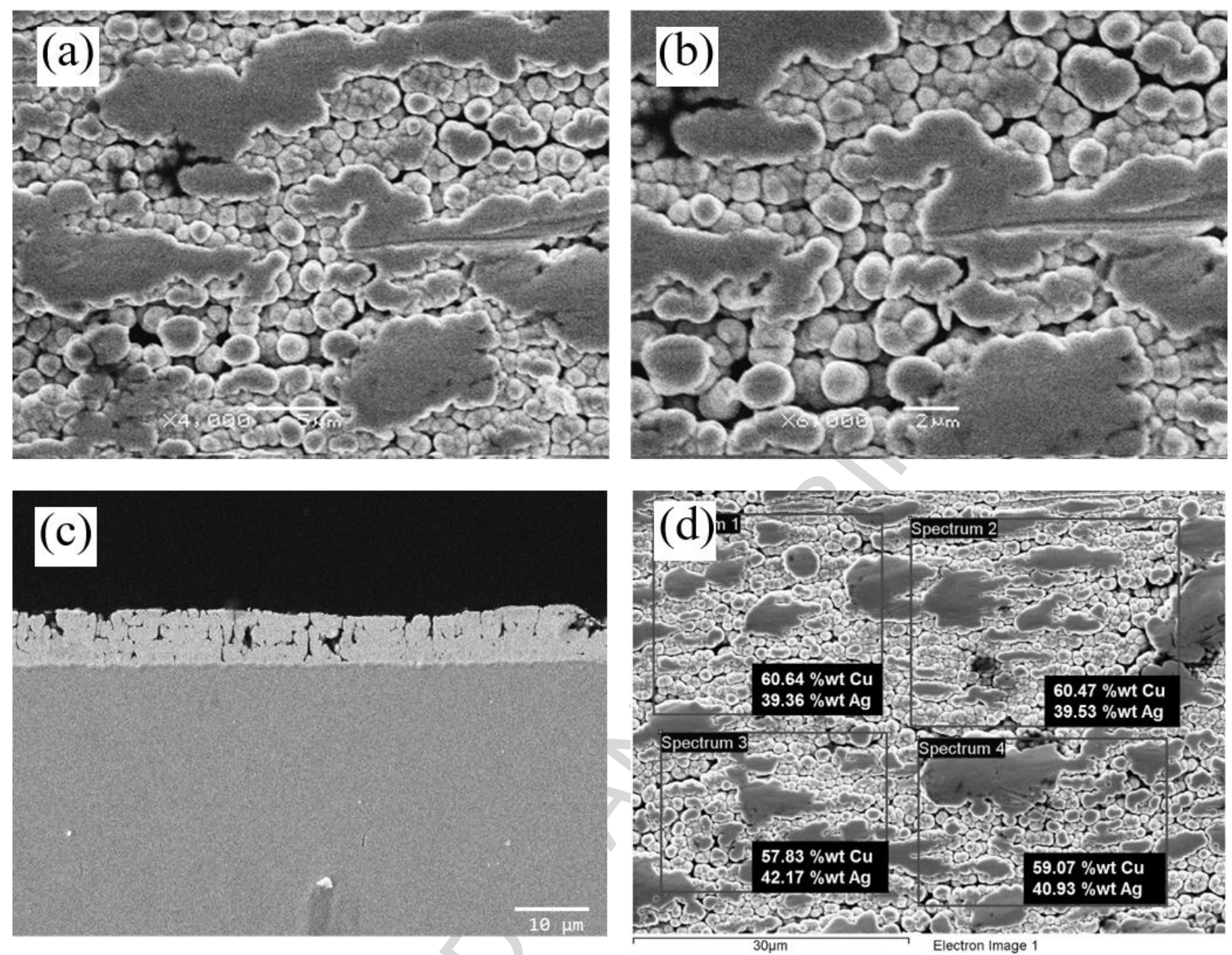

Fig. 3. 
ACCEPTED MANUSCRIPT

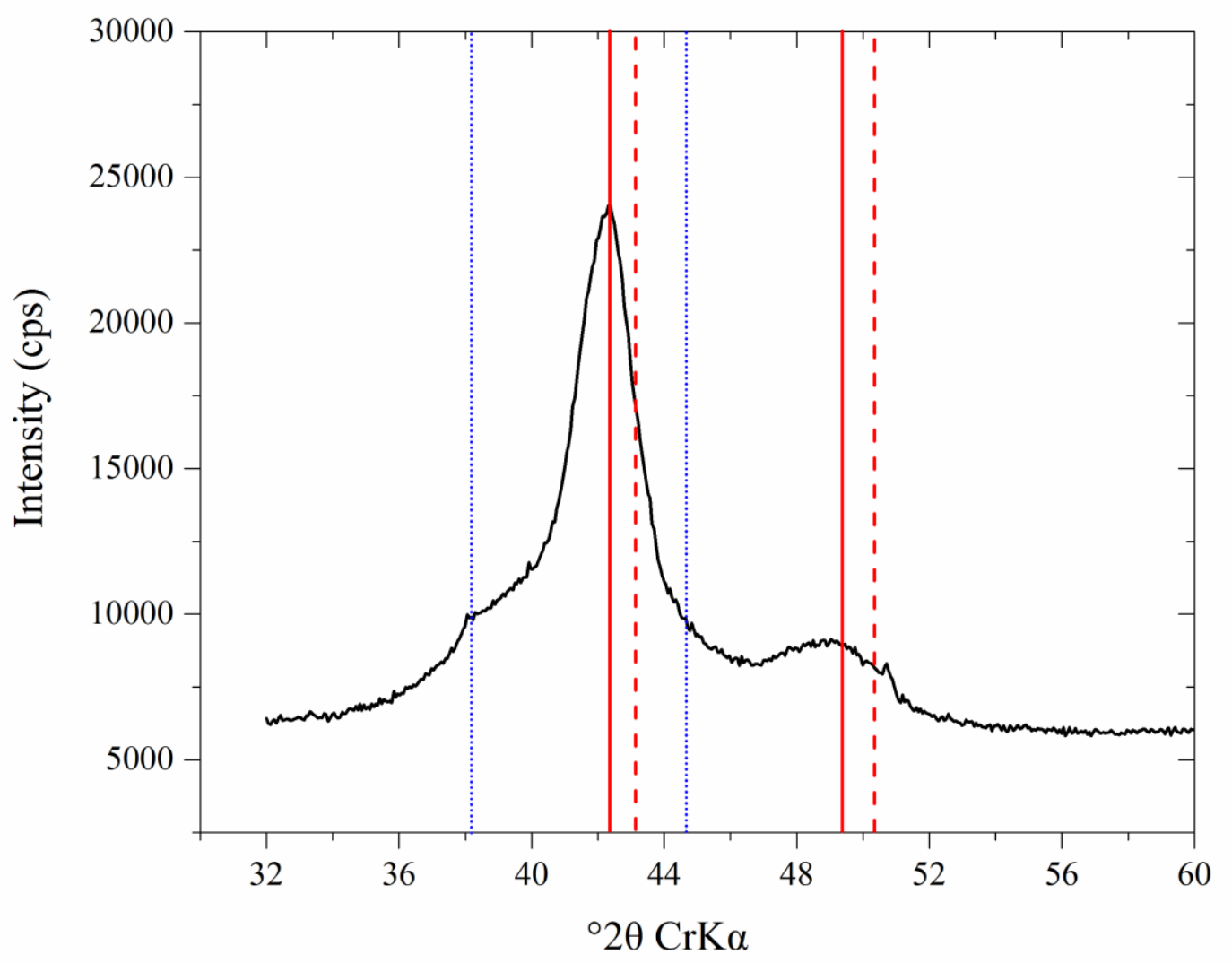

Fig. 4. 
(a)

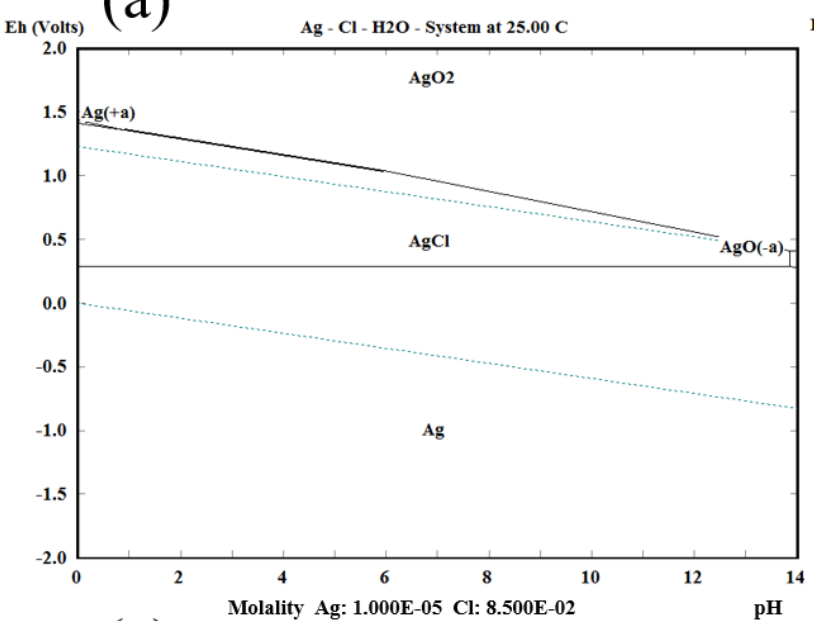

(c)

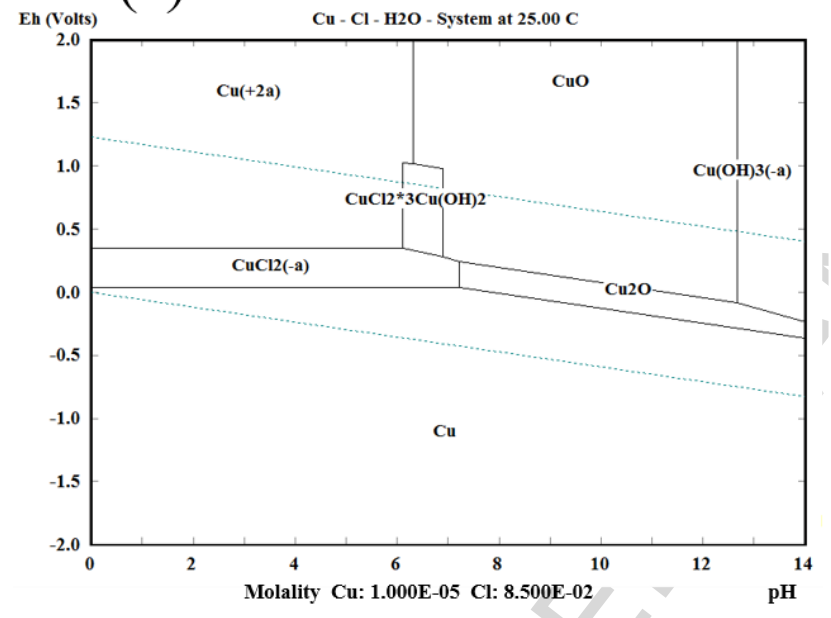

(b)

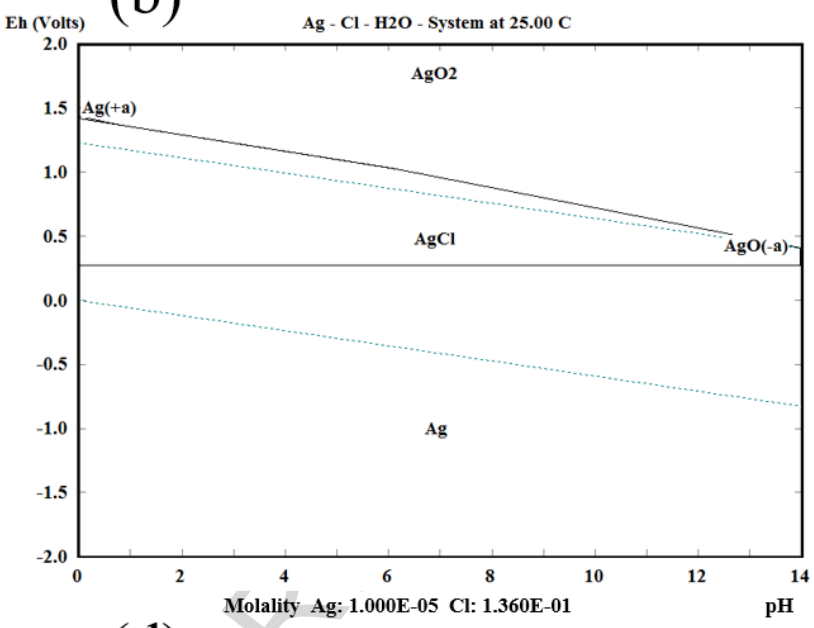

(d)

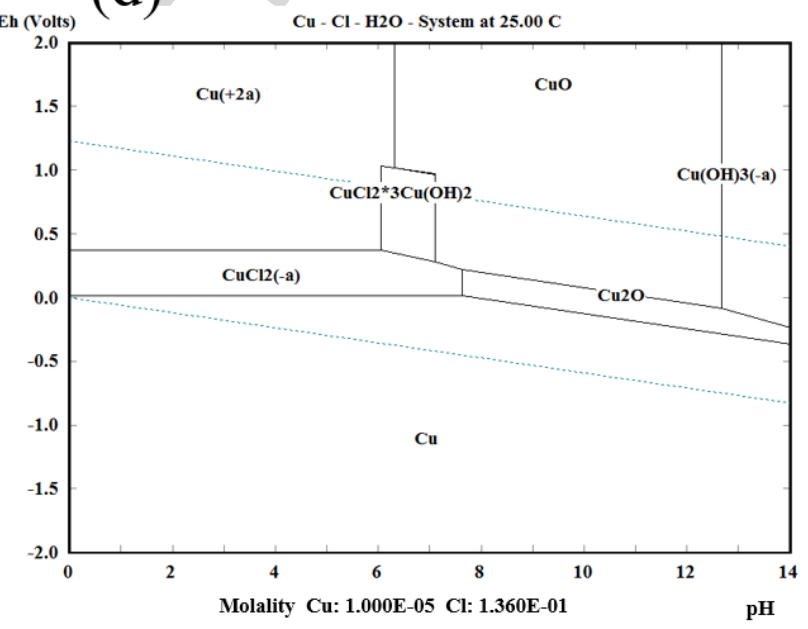

Fig. 5. 
(a)

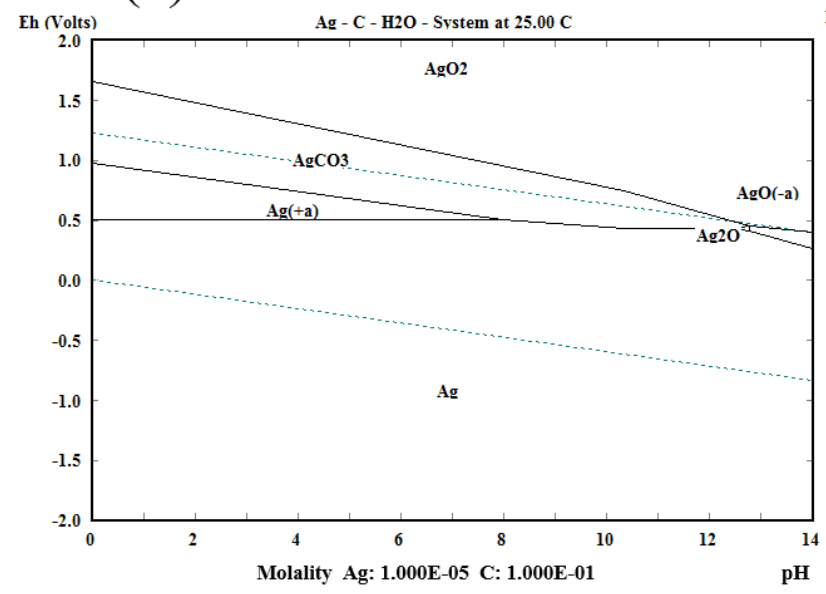

(b)

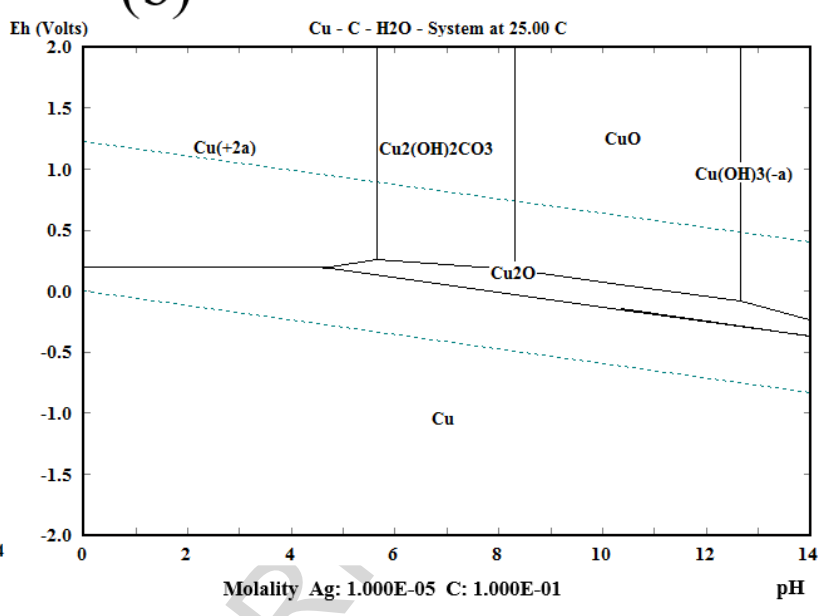

Fig. 6. 


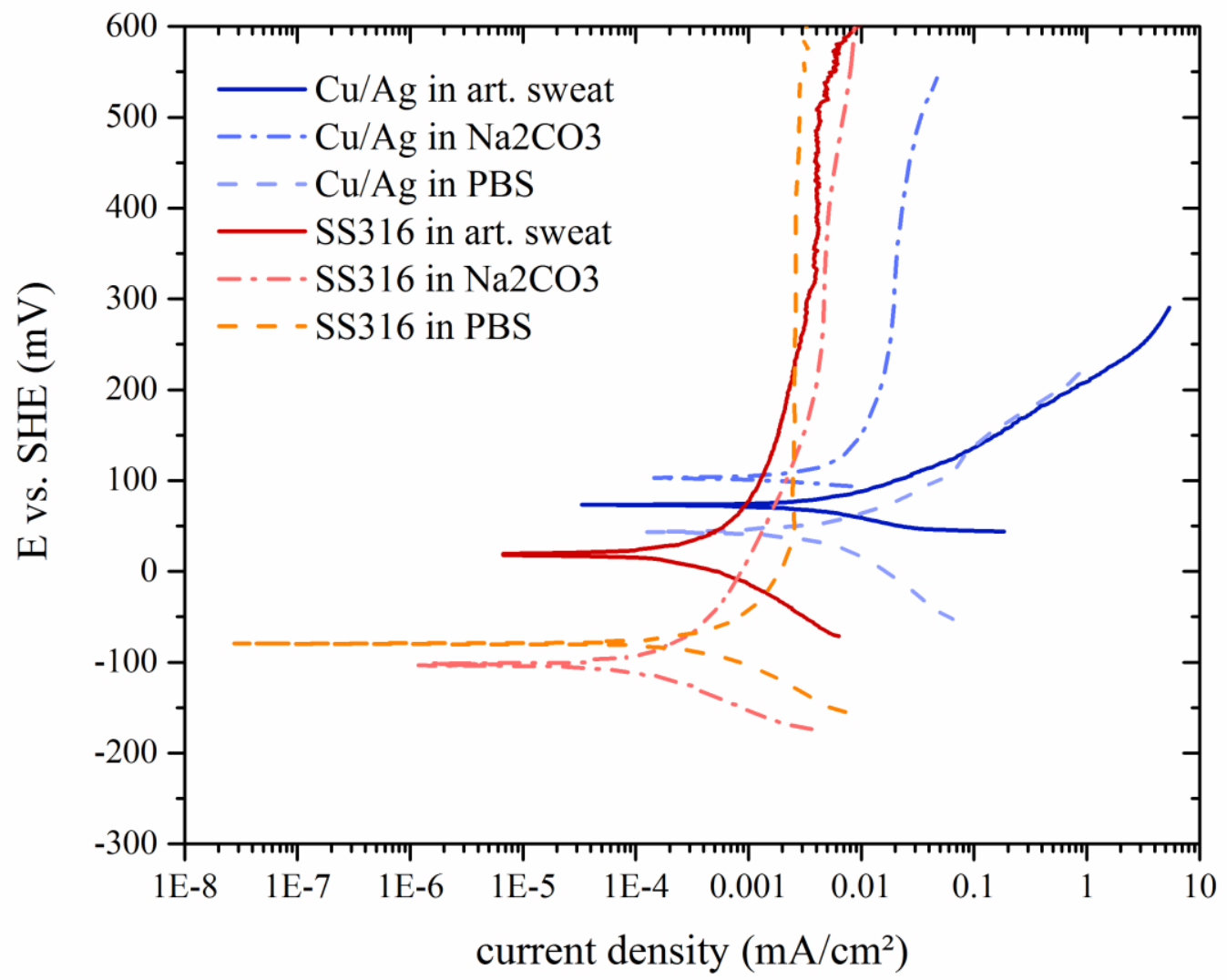

Fig. 7. 


\section{Highlights}

- Development of an electroplated copper-silver alloy coating for stainless steel.

- Demonstration of the antibacterial properties of the copper-silver alloy coating.

- Dissolution of copper ions is controlled by the galvanic coupling with silver. 